\title{
From Standpoint Epistemology to Epistemic Oppression
}

\author{
BRIANA TOOLE (D)
}

Standpoint epistemology is committed to a cluster of views that pays special attention to the role of social identity in knowledge-acquisition. Of particular interest here is the situated knowledge thesis. This thesis holds that for certain propositions $p$, whether an epistemic agent is in a position to know that $p$ depends on some nonepistemic facts related to the epistemic agent's social identity. In this article, I examine two possible ways to interpret this thesis. My first goal here is to clarify existing interpretations of this thesis that appear in the literature but that are undeveloped and often mistakenly conflated. In so doing, I aim to make clear the different versions of standpoint epistemology that one might accept and defend.

This project is of significance, I argue, because standpoint epistemology provides helpful tools for understanding a phenomenon of recent interest: epistemic oppression. My second goal is to provide an analysis that makes clear how each of the readings I put forth can be used to illuminate forms of epistemic oppression.

The landscape of epistemology is changing. Epistemologists are no longer concerned solely with questions regarding what conditions are necessary for knowledge or how knowledge is transmitted; they have instead shifted their attention to concerns regarding our epistemic practices and how those practices might oppress. Epistemic oppression, the unwarranted exclusion or obstruction of certain epistemic agents from the practices of knowledge-production (Dotson 2012, 2014), has been the focus of much work produced by feminist epistemologists in the last decade, and rightly so. If the aim of epistemology is to bring us closer to truth, then any practice that threatens to subvert this aim ought to be thoroughly investigated. ${ }^{1}$ In this article, I argue that in order to understand, address, and eliminate epistemic oppression, we must appeal to the conceptual tools made available by standpoint epistemology.

Broadly speaking, standpoint epistemology is committed to the thesis that some nonepistemic features related to an agent's social identity make a difference to what an epistemic agent is in a position to know (Hartsock 1983; Haraway 1988; Harding 
1993; Wylie 2003; Kukla 2006; Rolin 2009; Intemann 2010; Crasnow 2013). Precisely which features of an epistemic agent's social identity are of concern, and the way in which those features make a difference to what a person knows, is what I aim to explore further in this article.

The standpoint thesis is important but controversial. It owes its controversial nature to the fact that it stands in tension with those versions of traditional epistemology that suggest that it is exclusively epistemic features (such as truth, evidence, reliability, and so on) that make a difference to what a person is in a position to know. And, as I have already alluded, it is an important thesis because it sheds light on a phenomenon that emerges in our epistemic practices: epistemic oppression.

Though some standpoint epistemologists have gestured at the relationship between standpoint epistemology and epistemic oppression (Crasnow 2009; Rolin 2009), the connection has not been explicitly developed. I thus take up that project here. However, in order to make clear the role standpoint epistemology plays in illuminating this phenomenon, we must first do some important work to clarify the landscape. The thesis of standpoint epistemology has been characterized in a number of diverse (and sometimes conflicting) ways. So to better understand epistemic oppression, we must first be clear about the thesis under discussion. My goal here is to carve out the conceptual space so we have a clearer sense of what standpoint epistemology is, how it is to be defended, and to what ends it can be applied.

I begin in section I by analyzing what I take to be the bare, or general, standpoint thesis. I next explore how we can fill in this bare reading to offer additional versions of the thesis. In section II, I examine the historical-material and feminist-material readings offered by George Lukács and Nancy Hartsock, respectively. In section III, I develop a social reading, gestured at by Miranda Fricker and Gaile Pohlhaus, among others. Then, in section IV, I analyze how these readings can be usefully applied to illuminate some (though not all) well-known forms of epistemic oppression.

\section{Standpoint Epistemology: A Primer}

Feminist standpoint epistemologies are comprised of three core theses: situated knowledge, epistemic privilege, and achievement. The situated knowledge thesis will be my primary focus, as it is here where many standpoint epistemologies diverge. I define the situated knowledge thesis as follows:

(S) For certain propositions $p$, whether an epistemic agent is in a position to know that $p$ depends on some nonepistemic social facts about that agent.

This thesis, as I have articulated it here, does not specify which nonepistemic social facts make a difference to what the epistemic agent is in a position to know. However, of primary concern to the standpoint epistemologist is the relationship between one's position of marginalization or dominance in a social system and what one can know (or fail to know) given that social positioning. 
Let me say a bit about how this thesis should be understood. I mean to defend the claim that certain nonepistemic facts related to one's social identity may make a difference to what evidence one has, whether one recognizes evidence as such, what claims one entertains, and so on. One's social identity may "open one up" to evidence in ways that aren't modeled by traditional epistemologies. ${ }^{2}$ It is this sense in which one's social identity, a nonepistemic feature, makes a difference to what one is in a position to know. Or so I hope to show.

The situated knowledge thesis, as I define it, rests on a distinction between epistemic and nonepistemic features. This, I have suggested elsewhere, is part of the controversiality of the thesis. ${ }^{3}$ Although I will not offer here a precise definition of when a feature is epistemic, traditional epistemologies take epistemic features to be those features that are truth-conducive-that is, features that make a belief more likely to be true. Paradigmatic examples give us a strong grasp of this category of features: examples include evidence, justification, reliability, and so on.

Standpoint epistemologies, by contrast, stipulate that features beyond these, features that are traditionally taken not to be truth-conducive, may make a difference to whether an epistemic agent knows some proposition or not. This is the claim I hope to motivate here.

As aforementioned, the situated knowledge thesis is but one of a cluster of claims to which the standpoint epistemologist is committed. Standpoint epistemologies are additionally committed to the claims that some epistemic advantage can be drawn from the position of powerlessness (epistemic privilege), and that knowledge accessible from a particular social location is not given, but must be struggled for (achievement).

The epistemic privilege thesis goes hand in hand with the achievement thesis. According to the epistemic privilege thesis, one is not epistemically privileged in virtue of occupying a particular social location. Rather, epistemic privilege may be achieved through the process of consciousness-raising. ${ }^{4}$ Consciousness-raising functions to help members of a socially oppressed group critically examine the relationship between one's social situatedness and one's oppression (or oppressive role) within a social system (Ruth 1973; MacKinnon 1991).

Both the epistemic privilege and achievement theses have been discussed elsewhere in the literature. ${ }^{5}$ Therefore, these latter two theses will not be my primary focus. I have merely offered this discussion as a useful primer to any reader unfamiliar with the robust standpoint literature.

In what follows, I aim to accomplish two tasks. First, I'll briefly discuss the more familiar historical-material and feminist-material versions of the situated knowledge thesis. Though these forms of the thesis have fallen largely out of fashion, I'll suggest these readings are useful to illuminate a form of epistemic oppression recently introduced into our theorizing: epistemic exploitation (Berenstain 2016). Second, I'll develop a social reading of the standpoint thesis that has been gestured at in the literature, but has not been fully developed. 


\section{Something Old: Material Readings of (S)}

Standpoint epistemology can trace its genesis to the works of Karl Marx and Friedrich Engels, Georg Lukács, and their analyses of the proletarian standpoint (Marx 1867/1976; Lukács 1923/1971; Marx and Engels 1932/2001). The nonepistemic feature of significance in their analysis is that of material labor. Thus, I render this reading of (S) as follows:

$\left(\mathrm{S}_{\mathrm{M}}\right)$ For certain propositions $p$, whether an epistemic agent is in a position to know that $p$ depends on that agent's relationship to material labor.

This reading is general enough to capture both the historical-material reading and the feminist-material reading it inspired.

The historical-material account of standpoint epistemology explores the relationship between a society's mode of production and what one is in a position to know. The mode of production of interest to these accounts is capitalism. This account suggests that one's class position within a capitalist system - that is, whether one is a member of the capitalist or the laboring class - is relevant to what one is in a position to know. As Nancy Hartsock writes, "material life (class position in Marxist theory) not only structures but sets limits on the understanding of social relations," such that one's relationship to labor can be expected to have consequences for knowledge (Hartsock 1983, 286).

Feminist-material accounts, rather than examining the relationship between knowledge and one's social class (under capitalism), instead shift their analysis to the relationship between knowledge and gender (under capitalist patriarchy) (Smith 1974; Hartsock 1983; Jaggar 1983; Harding 1991). Feminist-material accounts accuse historical-material accounts of neglecting to attend to the unique ways in which women's labor - which is often unrecognized as such-is central to the system of reproduction (Young 1980; Hartsock 1983).

Whereas historical-material accounts investigate the emergence of a proletarian standpoint, feminist-material accounts argue for the emergence of a distinctly feminist standpoint. Much as class sets limits on knowledge, feminist-materialists argue that the institutionalized division of gendered labor under patriarchy structures social relations, thereby structuring our understanding of those social relations.

Many feminist-materialists have developed their accounts by exploring the "double shift" women must perform (Hochschild and Machung 1989). That is, women participate in the reproduction of labor power by turning commodities into consumable goods - the production of food, clothing, and other such tasks (Rubin 1975). However, women also engage in a second, unpaid shift at home, performing duties that allow for the maintenance of capitalism by reproducing workers. Taken literally, women produce a commodity in that they have children who will go on to become a part of the workforce. Moreover, they perform duties that sustain workers-preparing meals, cleaning, doing laundry, caring for family members, and a litany of other feminine-coded work. 
A shortcoming of feminist-materialism, one that I take to be responsible for the general decline of the view in feminist literature, is that it is too narrow in focus. These accounts neglect to attend to the myriad forms of labor that women are expected to perform, but that does not directly contribute to the (re)production of capital.

\section{Beyond Reproductive Labor}

Reproductive labor does not exhaust the category of gendered labor that women are expected to perform. Yet feminist-material accounts have failed to adapt to reflect the ways in which women's roles have evolved over time. ${ }^{6}$ Another shortcoming of feminist-material accounts is their inadequacy in accounting for the labor performed by people of color, especially women of color. These accounts can be redeemed, I suggest, in two ways: first, by exploring labor that is coded as feminine, but does not directly or essentially involve the reproduction of capital; ${ }^{7}$ second, by demonstrating the relevance of these accounts to understanding epistemic oppression. I will focus on the first task here and return to the second in section IV.

I suggest here that emotional and cognitive labor, performed disproportionately by women and people of color, are within the purview of feminist-materialism. Mirjam Müller defines emotional labor as a form of gender-specific exploitation that involves:

listening to the other's worries, sensing that something is going on and providing space for the other to talk about it, keeping in touch, remembering important things in the other's life etc. The currency of this type of emotional labour includes care, respect, attention, affection or empathy. (Müller 2018, 8; see also Hochschild 1985)

This form of labor is unevenly distributed among the genders and races, and women and people of color perform it to a disproportionate degree. In part, Müller argues, this is because of gendered assumptions that view women as suited to these tasks because they are nurturing by nature. And, as I will soon show, this is also due to the expectation that academics of color perform diversity-related service.

Kate Manne also explores the unequal division of emotional labor along the lines of gender. Manne argues that because goods like "attention, affection, admiration, sympathy, sex, and children (i.e., social, domestic, reproductive, and emotional labor); also mixed goods, such as safe haven, nurture, security, soothing, and comfort" are distinctively coded as feminine, women are viewed as obligated to provide these goods to men, and men see themselves as entitled to the provision of these goods (Manne 2018, 130).

Beyond emotional labor, women also find themselves beholden to performing cognitive labor. Cognitive labor includes the invisible mental work that involves organizing, keeping track of, and delegating tasks that need to be accomplished in order to manage one's household, office, and so on (Walzer 1996). Cognitive labor thus includes tasks like noticing you're low on toilet paper, that the kids have upcoming 
doctors' appointments, that laundry needs to be done in preparation for a trip, and other such tasks. Although men increasingly perform these chores, it is still the case that women are expected to keep mental track of what has to be done and thus are responsible for delegating.

As both Müller and Manne note, women are adversely impacted by the expectation that they perform this kind of labor. For instance, in academia, women researchers are disproportionately asked to advise students, engage in additional service requirements (like serving on committees), and provide support for male colleagues (Guarino and Borden 2017; El-Alayli, Hansen-Brown, Ceynar 2018). This impedes their career advancement because they have less free time than do their male counterparts (Müller 2018, 9). Further, women are punished when they fail to provide these services to which others believe they are entitled (Manne 2018, 111).

This is doubly true as it applies to people and women of color. Research shows that heavier service burdens are placed on people and women of color than on their white male colleagues to perform diversity-related work (Joseph and Hirshfield 2011; Nair 2014). Moreover, studies show that people of color perform this work to a disproportionate degree, leaving them less time to spend on work that contributes to their achieving tenure. Consequently, the taxation of this "invisible labor" ultimately contributes to the attrition of people of color within the academy (Social Sciences Feminist Network Research Interest Group 2017).

Feminist-material accounts of the standpoint thesis must consider these forms of labor that are demanded of women and people of color under white-supremacist, capitalist patriarchy, which views dominantly situated agents as entitled to the emotional and cognitive labor that marginalized agents provide. These forms of labor are, in many cases, prior to the reproduction of labor that feminist-materialists investigate, such as housework. That is to say, women and people of color are able to contribute to these systems of reproduction by first participating in the emotional and cognitive labor necessary for these systems to operate.

These forms of labor also result in different bodies of knowledge, given that the labor is divided along the lines of gender and race. Women of color, for instance, are better positioned than are their white, male colleagues to know about the needs of students from low-income and minority backgrounds (such as mentorship and advising) because they are the ones attending to tasks involving those students (Steele 2010, esp. ch. 2).

Though material accounts of standpoint epistemology are useful as we think about our lives as they are structured around labor, this is but one facet of the human experience. The narrow focus of these accounts prevents us from considering broader elements of our social experiences, outside and beyond work, that might also affect what we know. As such, I will now take up the social reading of standpoint epistemology, which explores the relationship between knowledge and one's social experiences. 


\section{Something New: A Social Reading}

Beyond exploring the impact of labor relations on knowledge, some feminist epistemologists are also concerned with the more general social conditions and relations in which epistemic agents are situated (Anderson 1995; Fricker 1999; Pohlhaus 2011; Dotson 2012). Other accounts of standpoint epistemology should focus more broadly, then, on the social experiences that socially marginalized knowers or groups share in virtue of their position of marginalization. As this reading is underdeveloped, I will spend considerably more time here developing this account.

Gaile Pohlhaus has argued that marginalized groups develop a body of conceptual resources so as to understand the experiences they have in virtue of their marginalization (Pohlhaus 2011). ${ }^{8}$ I will cash out this reading of the standpoint thesis in terms of the conceptual resources one develops and utilizes as a result of the social position one occupies:

$\left(\mathrm{S}_{\mathrm{S}}\right)$ For certain propositions $p$, whether an epistemic agent is in a position to know that $p$ depends on the conceptual resources possessed by that agent.

This reading is meant to capture the social version of $(S)$, in which one's social experiences (and the conceptual resources developed to understand those experiences) make the difference to what a person is in a position to know. Before I explore how a standpoint emerges on this account, first let me say a bit about conceptual resources.

\section{Conceptual Resources}

Pohlhaus writes that these resources are tools epistemic agents use for understanding and evaluating their experiences. These resources include language, concepts, and their associated criteria for sorting. Importantly, these resources "do not stand independently of experience" (Pohlhaus 2011, 718, italics in original). Rather, as epistemic agents, we employ these resources to make sense of our experiences, and when our conceptual resources are inadequate to that task, we reform and revise those resources as necessary. Thus conceptual resources are not stagnant but are subject to change as epistemic agents see fit.

Conceptual resources play an important epistemic role in directing our attention, in organizing our thought, and in structuring our reasoning. This being so, I will argue that these resources have important consequences for knowledge, especially if, as I will show, the conceptual resources an epistemic agent has depend, in some cases, on her social experiences. To defend this claim, I turn now to work from Miranda Fricker on epistemic injustice.

Fricker has argued that epistemic agents are marginalized when they are excluded from meaning-generating, or interpretive, practices. A meaning-generating practice is one that guides, shapes, or governs our way of thinking about things. For instance, 
legal scholarship governs what sort of acts we think of as unlawful. But, because women, for example, were formerly excluded from these practices, we neglected to consider and regulate the sorts of oppressive behaviors to which women are sometimes subjected - among these, sexual harassment, date rape, and marital rape.

Like Fricker, Pohlhaus argues that the exclusion of certain epistemic agents from participation in these meaning-generating practices has resulted in the marginalization of these agents. These agents are marginalized, she claims, because they lack the conceptual resources required to understand the experiences they have. ${ }^{9}$ Fortunately, Pohlhaus and Fricker both argue that marginalized epistemic agents, seeing the inadequacy of the available conceptual resources, can develop a new body of resources with which to understand their experiences. ${ }^{10}$

Consider, for example, the concept of "colorism." To my knowledge, Alice Walker first introduced this term, defining colorism as "prejudicial or preferential treatment of same-race people based solely on their color" (Walker 1983, 290-91). In particular, colorism involves discrimination against, or preferential treatment of, certain people because of their proximity to whiteness. This includes, for instance, preferring lighterskinned black people to darker-skinned ones. But it might also include, for example, discounting the narratives of lighter-skinned black people or refusing to consider them members of the black community.

I first experienced colorism as a senior in high school, though at the time I did not have the conceptual resources needed to understand my experience. A college recruiter from a historically black college/university (HBCU) visited to offer me a scholarship. But upon meeting me, he didn't review the offer with me; instead, he handed me a packet with information and immediately departed. I later gathered that it is unusual for a college recruiter to behave in this way, and I inferred that what ultimately best explained what happened was that he was surprised (and perhaps, disappointed) by the fact that I am a fairly light-skinned biracial woman.

At the time, I knew that there was something unnerving and hurtful about the experience. But, as I did not possess the concept for colorism, I did not fully understand what had occurred, or why. It wasn't until many years later, when I acquired the concept, that I recognized this as an instance of colorism. Learning this concept threw into sharp relief an experience that had been somewhat vague for me until then.

Moreover, learning this concept helped me to recognize other instances of colorism that I had previously overlooked. For instance, I began to notice that when black actresses are featured on the cover of magazines, they are often whitewashed (Gordon 2015). Still further, it appears that more roles are made available for lighter-skinned black actresses than for darker-skinned actresses (Onyejiaka 2017). And lighter-skinned actresses, models, and singers appear on magazine covers more often than their darker-skinned peers (Wilson 2018).

The development of the concept of "colorism" better helps us attend to a phenomenon that was otherwise uninterrogated. This concept goes beyond "racism," which merely involves discrimination based on race, and is meant to capture a more nuanced form of tone-based discrimination whereby people are rewarded for 
presenting as white, and ostracized when they fail to. It therefore captures a wide range of experiences that "racism" will make obscure or opaque.

A number of other conceptual resources have been developed by marginalized communities to attend to the unique aspects of their social experiences. Examples include "misogynoir," as coined by Moya Bailey, which describes the particular form of racialized sexism that black women face (Bailey 2013); the term "microaggression," which captures the subtle forms of discrimination that people of color and women experience daily (Sue 2010); and as Fricker has noted, "sexual harassment," a concept that enables women to better understand and identify the workplace harassment to which they were subjected.

I argue that the development of these resources depends on the social experiences that we have. Women of color experience misogynoir when they are accused of being overly angry or overly sexual as compared to other women; Latinx individuals experience a microaggression when they are routinely asked where they are really from; and women experience sexual harassment when their bodies are sexualized in the workplace.

That such resources were previously unavailable, but were needed to describe these experiences, is what ultimately led to their development. Moreover, the usefulness of these concepts is evaluated by their ability to fulfill this need. Thus, a conceptual resource is developed to fill some gap in our conceptual understanding, but these resources travel only if they are found to be useful by those who are similarly situated. $^{11}$

Marginalized groups need terms that enable them to make sense of these experiences. These resources help marginalized knowers understand what they are experiencing and attend to similar experiences in the future.

Dominantly situated knowers, who do not have these experiences, will not need these resources. Thus the conceptual resources we develop will often depend on the social experiences that we need to describe. Consequently, I suggest that marginalized knowers and dominantly situated knowers, because they have different social experiences, will develop a different body of conceptual resources. If epistemic agents do not have particular conceptual resources, it will be difficult for them to notice or attend to the facts picked out by those resources.

To illustrate, dominantly situated knowers who lack the concept of colorism may fail to realize that this is what I experienced in the example described above. In fact, they may fail to see that anything untoward happened at all. Or, it may strike them as an ordinary occurrence that warrants no further investigation.

Of course, even when dominantly situated knowers come to learn of these conceptual resources, there may still be an issue of uptake. Although newly developed conceptual resources may become intercommunally shared, dominantly situated knowers may be initially reluctant to adopt the resources developed by marginalized communities. In part, this is because dominantly situated knowers may suspect that the newly developed concept picks out, or attends to, nothing (Pohlhaus 2011). As such, there are whole parts of social reality that marginalized knowers are well positioned to investigate and analyze, and that dominantly situated knowers may ignore entirely. 
Conceptual resources are but one part of the social standpoint, however. Work must be done, still, to explain how a social standpoint emerges. Let me turn to that task now.

\section{A Social Standpoint}

As I said earlier, feminist epistemologists who offer a social account of the standpoint thesis shift their analysis from one's relationship to labor to the social experiences knowers (or groups) have as a consequence of their marginalization. Consequently, a standpoint emerges, in part, as a result of the shared social experiences of a particular marginalized group. Additionally, as I suggested above, the emergence of a standpoint depends on members of that marginalized group developing the conceptual resources necessary to understand their social experiences.

A standpoint may emerge in several stages. The first stage occurs when a group of people share that they have had a similar social experience, and recognize that this experience is one they have because of some aspect of their social identity. As an example, consider a group of black men and women who confide in one another that they have been excluded from certain events or groups because they are darkerskinned, or have been subject to greater punishment or harsher treatment than their lighter-skinned peers, even when they engage in the same sort of behavior. This group will come to realize that this is an experience they all share, and that it is an experience they share because they are dark-skinned.

This is the stage of consciousness-raising. Consciousness-raising, applied to this example, involves dark-skinned black people coming to the realization that there are experiences they share just in virtue of the fact that they are darker-skinned. It thus involves moving beyond the realization that 1) they are all dark-skinned and 2) that this is an experience they all happen to share. That is to say, it requires that they realize that it is an experience they share in virtue of their skin tone.

The second stage involves naming this experience. This requires developing the concept, if one does not exist already, to appropriately capture the experience they share. Thus, we see the development, for instance, of the term "colorism" to name the experience this group shares as a result of being dark-skinned. Equipped with this concept that names their social experience, members of this group are well positioned to notice other instances of colorism.

We might ask how this account differs from the material accounts developed above. In part, my task here has been to show that these are distinct accounts that have not been properly distinguished in the literature. The social account of the standpoint thesis differs fundamentally from the material reading in the following respects.

First, whereas both versions of the standpoint thesis share as a common assumption that certain relationships structure our understanding, they differ with respect to which relationships they take to do the structuring. For material accounts, epistemic agents understand the world through their relationship to labor. Thus, my understanding of the world is structured in part by the fact that I am a laborer. The social 
account, by contrast, examines how we understand the world from an embodied perspective - as individuals who are raced, sexed, gendered, and so on.

Second, whereas the social account depends on the development of conceptual resources for the emergence of a standpoint, the material account does not. In part, this is because we all bear some relationship, however minor, to labor. As such, the conceptual resources needed to understand labor are readily available. That is to say, the resources that enable women and people of color to understand their activities as labor are available. The same is not true for social experiences, for which the conceptual resources needed for understanding are developed largely with the experiences of the dominant in mind.

Third, and finally, the locus of epistemic oppression differs on each account, as well as the method for dismantling this oppression. Materially based epistemic oppression occurs not because one lacks the conceptual tools to understand one's oppression, but rather because those conceptual tools are unjustly applied. Socially based epistemic oppression, by contrast, happens because one is without the conceptual tools needed to understand and communicate one's experiences of oppression. I expand on this further in section IV.

\section{Applications of Standpoint Epistemology}

I have endeavored in the previous sections to establish two points. First, I argued that whether an epistemic agent is in a position to know some proposition in the social domain will depend on some nonepistemic facts related to the agent's social identity. Second, I argued that one's relationship to labor and one's social experiences (and the concepts developed to understand those experiences) are two such nonepistemic social facts that affect the production and acquisition of knowledge.

The project of exploring the relationship between social situatedness and knowledge is interesting in and of itself. But it is also a necessary project if we are to understand how and why the phenomenon of epistemic oppression arises.

Following Kristie Dotson, I define epistemic oppression as "persistent epistemic exclusion that hinders one's contribution to knowledge production," where epistemic exclusion is understood as "an unwarranted infringement on the epistemic agency of knowers” (Dotson 2014, 115). Epistemic oppression occurs when some group (or members of some group) suffers some form of epistemic injustice in a systematic way. I will focus here on three epistemic injustices discussed in the literature: hermeneutical injustice, willful hermeneutical ignorance, and epistemic exploitation.

A hermeneutical injustice is one in which a marginalized knower's "social experience remains obscure and confusing, even for them" because those experiences are excluded from collective understanding (Fricker 1999, 208). To illustrate, my inability to recognize my experience with the college recruiter as an instance of colorism is a hermeneutical injustice that occurred because I lacked the term colorism.

Willful hermeneutical ignorance, on the other hand, occurs when a dominantly situated knower refuses to acknowledge or use the conceptual tools developed by 
marginalized knowers and, as such, fails to understand or misinterprets parts of the world (Pohlhaus 2011). This happens, for instance, if, when I try to share with someone my experience of colorism, they refuse to accept that colorism is a real phenomenon and so dismiss my interpretation of an event as an instance of colorism.

Lastly, epistemic exploitation occurs "when privileged persons compel marginalized persons to produce an education or explanation about the nature of the oppression they face" (Berenstain 2016, 570). According to Berenstain, epistemic exploitation is oppressive because it is "marked by unrecognized, uncompensated, emotionally taxing, coerced epistemic labor" (570). As an illustration, epistemic exploitation occurs when, for instance, someone asks me about my experiences of colorism, but then expresses skepticism that my experiences really happened as I have described, or instead tries to explain them away.

Below, I will argue that hermeneutical injustice and willful hermeneutical ignorance can be understood using the social reading of the standpoint thesis, and that epistemic exploitation can be understood using the material reading of the thesis.

\section{Epistemic Oppression And the Social Reading}

There's a clear sense in which hermeneutical injustice and willful hermeneutical ignorance are tied to the social reading of $(\mathrm{S})$. Thinking about standpoint epistemology in terms of conceptual resources, and the relationship between a knower's social location and the conceptual resources she employs, helps to make clear why these forms of epistemic oppression occur.

First, it helps to distinguish between intercommunally shared epistemic resources and intracommunally shared epistemic resources. A pool of resources is intercommunal when those resources are shared both within and across groups. By contrast, intracommunal resources are those resources that are shared primarily within a given community of interlocutors.

Intercommunal resources have been influenced largely by dominantly situated knowers, in part because, as I discussed earlier, marginalized knowers are largely excluded from the meaning-generating practices in which we develop new conceptual resources. The result is that our intercommunal conceptual resources are often not suited to make sense of the experiences of the socially marginalized.

Prior to the development of intracommunal conceptual resources needed to understand these experiences (for example, sexual harassment, colorism, and so on), marginalized groups use the resources of the dominant standpoint. Those resources, which were not developed with the social experiences of the marginalized in mind, are not useful to marginalized groups as they attempt to interpret their social experiences. This results in a hermeneutical injustice.

According to Fricker, hermeneutical injustice occurs when a person's "social experience remains obscure and confusing, even for them" because those experiences are excluded from the collective understanding (Fricker 1999, 208). Thus, on Fricker's view, hermeneutical injustice occurs when knowers are unable to make sense of some 
aspect of their world because they have been excluded from playing a part in the collective understanding. Thus, one's experiences are obscured, even from one's self, because the interpretive resources necessary to make sense of those social experiences have not yet been developed.

To illustrate, Fricker points to a memoir from Susan Brownmiller that details what we today name sexual harassment. Brownmiller recounts the experience of Carmita Wood - an employee in the Cornell Department of Nuclear Physics - and a group of students who discover that they have all had similar experiences of being groped by men while in their workplace. ${ }^{12}$ Brownmiller describes the women's decision to have a "speak-out in order to break the silence about this," only to realize that the "this" they were going to break the silence about had no name" (Brownmiller 1990, 281; quoted in Fricker 2007, 150).

According to Fricker, the existing hermeneutical resources left a "lacuna where the name of a distinctive social experience should be" (Fricker 2007, 150-51). As a result, these women lacked a proper understanding for what we are now easily able to identify as sexual harassment. They were thus wronged, in their capacity as knowers, in that they were prevented from understanding a significant part of their social experience.

It is because $\left(S_{S}\right)$ reveals that our conceptual resources are not independent of our social experiences that we are able to see the way in which marginalized groupswhose experiences are not reflected in our intercommunal conceptual resources - suffer a hermeneutical injustice. Of course, epistemic injustice does not cease once hermeneutical injustice is eliminated, as the work still remains for those resources to be received within the larger social world. Thus, even when hermeneutical injustices are largely addressed, marginalized groups may still be subject to willful hermeneutical ignorance as they attempt to communicate their experiences to dominantly situated knowers.

Willful hermeneutical ignorance occurs after marginally situated knowers have developed their own conceptual resources and when two conditions are met. First, marginally situated knowers have developed conceptual resources such that they are able both to understand and communicate their experience to others. And second, these conceptual resources are dismissed by dominantly situated knowers, thus rendering unintelligible the claims made by marginally situated knowers.

Consider, as an illustration, the concept of "marital rape." Until epistemic agents began to use the conceptual resources necessary to understand marital rape, many failed to recognize that a rape victim's perpetrator could be his or her spouse. As such, we failed to afford these victims protections against this sort of abuse until well into the 1990s (Ryan 1995).

The situatedness of the dominant knower will not make salient those features of the world that the marginalized knower's conceptual resources attend to. As a result, the dominant knower can use this fact to preemptively dismiss the knowledge claims of a marginalized knower, as well as to dismiss the conceptual resources required to understand those knowledge claims. This happens because the resources the marginalized group is using will appear to the dominantly situated knower to "attend to 
nothing at all, or make something out of nothing" (Pohlhaus 2011, 722). This occurs particularly because those resources draw attention to features that are not within the experienced world of the dominantly situated knower.

Consequently, dominantly situated knowers may dismiss the conceptual resources developed from the perspective of marginalized standpoints before learning to use them. When a marginally situated knower's conceptual resources and knowledge claims are dismissed in this way, the knower is subject to willful hermeneutical ignorance.

In both the case of hermeneutical injustice and willful hermeneutical ignorance, we see that marginalized knowers are obstructed in their capacities as knowers. This obstruction, again, is due to the inadequacy of the prevailing conceptual resources, either to understand the social experiences of marginalized groups, or to allow for marginalized groups to effectively communicate those experiences to dominantly situated knowers.

Next, let me turn to the material reading and its applications to epistemic exploitation.

\section{Epistemic Oppression and the Material Reading}

Just as the epistemic reading of the standpoint thesis served to investigate hermeneutical injustice and willful hermeneutical ignorance, the material reading of the thesis makes clear why epistemic exploitation occurs. Epistemic exploitation is a form of epistemic oppression in which marginalized knowers are expected to educate dominantly situated knowers about their oppression. Epistemic exploitation might involve, for instance, a woman of color being asked to explain to white women why it is inappropriate for them to touch her hair. This work is exploitative, Berenstain argues, because it is often unrecognized and uncompensated, and places an unfair burden on those who are already marginalized.

I argue that both emotional and cognitive labor constitute forms of epistemic exploitation. Rather than thinking of emotional and cognitive labor as being exploited in service of some other form of oppression, I argue that in and of themselves, these forms of labor are exploitative. Including emotional and cognitive labor in this category captures the notion that, in performing this sort of labor, the mental energy of women and people of color is diverted away from their own projects, goals, and interests in the service of someone else's. Emotional and cognitive labor, like other forms of epistemic exploitation, "[maintain] structures of oppression by centering the needs and desires of dominant groups" (Berenstain 2016, 570).

Material accounts of standpoint epistemology investigate the role of material conditions (and the way in which we organize our lives around those conditions) in shaping inquiry. In particular, material accounts examine capitalism, and I have suggested, capitalist patriarchy. Primarily, this is because capitalism and capitalist patriarchy serve to legitimize, or justify, the material conditions they bring about. I suggest that capitalism and capitalist patriarchy perform this function through a 
number of means. In particular, I will focus here on the role of schemas and legitimizing myths.

Virgina Valian writes that a schema is a "mental construct that . . . contains in schematic or abbreviated form someone's concept about an individual or event, or a group of individuals or events. It includes the person's or group's main characteristics, from the perceiver's point of view, and the relationship among those features" (Valian 1998, 103). Gendered schemas, for instance, depict women as nurturers and caregivers, and men as warriors and providers (Haslanger 2008).

Legitimizing myths, by contrast, are social narratives that serve to justify and maintain the position of dominant groups in a social hierarchy (Sidanius and Pratto 1999). Such myths attempt to naturalize social hierarchies by treating these hierarchies as naturally mandated. They further "[indicate] how individuals and social institutions should allocate things of positive or negative social value" and serve as explanations for how the world is (Pratto et al. 1994, 741). For example, they may justify existing systems of inequality by indicating that inequality is due to the innate inferiority of some groups compared to others (for example, white nationalism, social Darwinism, and so on). Legitimizing myths include, for instance, racism and sexism, which provide a moral justification for discrimination along the lines of race and gender.

Schemas function to shape our expectations, aid in the formation of generalizations, and make sense of the social world, and legitimizing myths serve to justify the social world as structured. In a sense, legitimizing myths justify our schemas by suggesting that those schemas reflect natural social arrangements. Schemas, in turn, justify the maintenance and replication of unequal social relations such that the world matches our expectations of it. ${ }^{13}$

As Roland Barthes writes, "What the world supplies to myth is an historical reality . . . and what myth gives in return is a natural image of this reality" (Barthes $1957 / 1972,142$ ). What Barthes means by this is that myth takes something historical and gives it the appearance of being ahistorical, apolitical, and universal.

Consider, for instance, that our historical reality is one in which women have occupied roles traditionally afforded a lower social status - as nurses, wives, mothers, and so on. The occupation of these roles is justified by schemas that frame women as emotional, subjective, life-giving, and nurturing (Valian 1998; Haslanger 2008). These schemas are in turn legitimized by social myths that characterize women as, by nature, caring and giving (for example, biological sexism and biological determinism). Thus, the gendered division of labor under capitalist patriarchy is justified by appealing to these schemas and myths. ${ }^{14}$

Capitalism and capitalist patriarchy justify the material conditions they produce by the construction and maintenance of these schemas and legitimizing myths. They thereby justify the material oppression produced as a consequence. Legitimizing myths and schemas work together to engender a sort of blindness that inures us to the oppression produced by capitalism and capitalist patriarchy. Schemas and myths thus render invisible the oppressive features of capitalism and capitalist patriarchy to those who benefit from it. 
Material accounts of the standpoint thesis draw our attention to how capitalism and capitalist patriarchy structure social relations. They thereby demand that we interrogate the oppressive social systems they enact and maintain. Material accounts successfully accomplish this by making central the role of practical productive interactions in producing knowledge. Social scientists Jack Spaapen and Leonie van Drooge define productive interactions as:

exchanges between researchers and stakeholders in which knowledge is produced and valued that is both scientifically robust and socially relevant. These exchanges are mediated through various "tracks," for instance, a research publication, an exhibition, a design, people or financial support. The interaction is productive when it leads to efforts by stakeholders to somehow use or apply research results or practical information or experiences. Social impacts of knowledge are behavioural changes that happen because of this knowledge. These changes may regard human well-being ("quality of life") and/or the social relations between people or organizations. (Spaapen and van Drooge 2011, 212; italics in original)

Thus, productive interactions yield information or experiences that are socially impactful in improving social relations.

This analysis of productive interactions is too narrow for my purposes. Practical productive interactions, I suggest, are broader so as to include those exchanges analyzing practical experiences and social roles. In particular, practical productive interactions are those interactions in which one attends to the type of labor in which they are engaged and the relation between that labor and one's social relationships of production. Social relationships of production are those relationships we must enter into in order to survive, produce, and reproduce our means of life.

In Marxist terms, practical productive interactions thus involve investigating how one's social positioning (as a laborer) is the result of a specific set of historical conditions. Namely, it involves realizing that one is a laborer in relation to a capitalist under a set of social conditions, that is, capitalism. Practical productive interactions thus require that we critically interrogate the conditions of one's labor and what structures make those conditions possible, that is, the supporting schemas and myths.

This point also holds for the feminist-materialist. Practical productive interactions involve an examination of how one's status as, for instance, a caregiver (physically or emotionally) exists under a set of social conditions in which men are entitled to that care, that is, patriarchy. Thus, we see that emotional and cognitive labor is labor demanded of women and people of color, and owed to men, given the social relationships of production under capitalist patriarchy.

Like productive interactions, practical productive interactions yield knowledge that is socially impactful. In practical productive interactions, however, the knowledge produced is knowledge of the schemas and legitimizing myths that are taken to justify one's oppression. Practical productive interactions thus require a reassessment of the schemas that have been taken for granted even by those occupying marginalized social positions. 
Dominantly situated knowers are unlikely to have such practical productive interactions, both because they aren't expected to engage in these forms of labor, and because they have come to represent these inequalities as reflecting nature. Moreover, the social relationship that dominantly situated knowers stand in is that of beneficiary of the labor of others. For instance, the capitalist stands in relation to capital goods; men stand in relation to emotional caregiving. Thus, there is no need for them to consider the work that goes into the production of that good, so long as the good is produced.

In the case of epistemic exploitation (and emotional and cognitive labor), marginalized knowers are prevented from recognizing their labor as labor, and from sharing knowledge of this fact once they acquire it. This occurs because capitalism and capitalist patriarchy make this labor invisible to the dominantly situated, and justify it by appeal to legitimizing myths and schemas. As these tools are successful to the extent that they seem to "naturalize" inequalities, material accounts undermine these tools by questioning the legitimacy of these claims.

\section{The Value of Standpoint Epistemology}

Epistemic oppression has long been a feature of our existing epistemic practices. This oppression has been neither subtle nor hidden, merely obscured from our understanding. My aim has been to show that standpoint epistemology is useful in that it gives us the tools needed to understand a practice that was previously occluded.

In the previous sections, I discussed various forms of epistemic oppression, and explored how each form can be illuminated by versions of the standpoint thesis. I argue that it is by appealing to the standpoint epistemologist's project that these forms of epistemic oppression are revealed.

Epistemic oppression occurs, in large part, because marginalized knowers know some social facts that dominantly situated knowers can't, or find difficult to, know. As a result, dominantly situated knowers tend to discount the knowledge claims of marginalized knowers. In order to interpret certain cases as instances of epistemic oppression, we first need an epistemological framework that acknowledges that, and establishes how, socially marginalized knowers come to have a body of knowledge that dominantly situated knowers lack (or struggle to access). Standpoint epistemology provides such a framework. The task before us is to construct additional readings of the general thesis that enable us to understand forms of epistemic oppression that are not captured by the readings heretofore provided.

\section{NOTES}

Thanks to Sinan Dogramaci, Kristie Dotson, Louise Antony, and Sally Haslanger for many helpful conversations and suggestions. Thanks, as well, to audiences at the University of Texas at Austin and the University of Toronto for their insightful questions and 
feedback. I would also like to note that the anonymous referees for this article were extremely helpful and encouraging, and I appreciate their sincere engagement.

1. For interpretations and defenses of the dictum that "belief aims at truth," see Railton 1994; Velleman 2000.

2. By traditional epistemologies, I mean "S-knows-that-p" epistemologies. For more, see Code 1995, esp. ch. 2.

3. For a more thorough examination of the tension between standpoint and traditional epistemologies, see Toole (2017).

4. Consciousness-raising is somewhat undertheorized in discussions of feminist epistemology. As such, it is an open question whether consciousness-raising is sufficient for epistemic privilege, or if there are other routes by which such privilege may be achieved.

5. Defenses of the epistemic privilege thesis can be found in Hartsock 1983; Collins 1986; Wylie 2003; and Rolin 2009. The achievement thesis has been discussed in Ruth 1973; Harding 1991; and MacKinnon 1991, to name but a few.

6. For more on this, see Collins 1986.

7. One could, of course, argue that these forms of labor do make the reproduction of labor possible, but this is not essential to their performance. That is to say, we can imagine cases in which this labor does not contribute to the production of capital. We may perform emotional labor for our friends, for instance, but it's difficult to see how, in doing so, we have contributed to the reproduction of capital.

8. Pohlhaus refers to these as epistemic resources, but I will refer to these as conceptual resources so as to avoid the implication that these resources are epistemic features.

9. This is what Fricker refers to as a hermeneutical injustice (Fricker 1999).

10. Fricker used the work of Susan Brownmiller and the case of Carmita Wood to argue that women developed the concept of sexual harassment to fill a void in the existing conceptual lexicon.

11. Thank you to an anonymous reviewer at Hypatia for drawing my attention to this point.

12. Although Fricker fails to note this fact, it is important to acknowledge that Carmita Wood is a black woman, as gendered racism (for example, the view of black women as hypersexual; see Crenshaw 1991) is relevant to her experience of sexual harassment and to her understanding of that experience.

13. One might point out here that schemas are conceptual, and so to understand and dismantle material oppression seems to rely on some conceptual apparatus. I suggest that schemas function as conceptual roadblocks that foreclose classifying certain activities, largely those performed by women and people of color, as labor. But again, this is due not to the unavailability of conceptual resources, but to the unjust application of existing resources. Thus, to dismantle material oppression does not require the development of new conceptual recourses, but that we ensure that existing conceptual resources are applied more justly.

14. The same can be said of racial stratifications. As is well known, the use of Africans as slaves preceded the belief that blacks were intellectually and morally inferior. That blacks are thought to be intellectually and morally inferior was used later to justify social relations that had already been brought about (Alexander 2010, esp. ch. 1). Thus we see that our historical reality (the racial caste system) was justified by the myth that blacks are irrational, impulsive, and so on. 


\section{REFERENCES}

Alexander, Michelle. 2010. The new Jim Crow: Mass incarceration in the age of colorblindness. New York: The New Press.

Anderson, Elizabeth. 1995. Feminist epistemology: An interpretation and a defense. Hypatia 10 (3): 50-84.

Bailey, Moya. 2013. New terms of resistance: A response to Zenzele Isoke. Souls 15 (4): $341-43$.

Barthes, Roland. 1957/1972. Mythologies. Trans. Annette Lavers. New York: Noonday Press.

Berenstain, Nora. 2016. Epistemic exploitation. Ergo 3 (22): 569-90.

Brownmiller, Susan. 1990. In our time: A memoir of revolution. New York: Dial Press.

Code, Lorraine. 1995. Rhetorical spaces: Essays on gendered locations. New York and London: Routledge.

Collins, Patricia Hill. 1986. Learning from the outsider within: The sociological significance of black feminist thought. Social Problems 33 (6): 14-32.

Crasnow, Sharon. 2009. Is feminist theory a resource for feminist epistemology? An introduction. Hypatia 24 (4): 189-92.

- 2013. Feminist philosophy of science: Values and objectivity. Philosophy Compass 8 (4): 413-23.

Crenshaw, Kimberlé Williams. 1991. Mapping the margins: Intersectionality, identity politics, and violence against women of color. Stanford Law Review 43 (6): 124199.

Dotson, Kristie. 2012. A cautionary tale: On limiting epistemic oppression. Frontier 33 (1): 24-47.

- 2014. Conceptualizing epistemic oppression. Social Epistemology 28 (2): 115-38.

El-Alayli, Amani, Ashley A. Hansen-Brown, and Michelle Ceynar. 2018. Dancing backwards in high heels: Female professors experience more work demands and special favor requests, particularly from academically entitled students. Sex Roles 79 (3-4): $136-50$.

Fricker, Miranda. 1999. Epistemic oppression and epistemic privilege. Canadian Journal of Philosophy 29 (supp. 1): 191-210.

- 2007. Epistemic injustice: Power and the ethics of knowing. Oxford: Oxford University Press.

Gordon, Taylor. 2015. 8 cases where a black celebrity was whitewashed for a magazine cover or ad campaign. Atlanta Black Star, February 19. https://atlantablackstar.com/ 2015/02/19/8-cases-where-a-black-celebrity-was-whitewashed-for-a-magazine-cover-orad-campaign/2/.

Guarino, Cassandra M., and Victor M. H. Borden. 2017. Faculty service loads and gender: Are women taking care of the academic family? Research in Higher Education 58 (6): 672-94.

Haraway, Donna. 1988. Situated knowledges: The science question in feminism and the privilege of partial perspective. Feminist Studies 14 (3): 575-99.

Harding, Sandra. 1991. Whose Science? Whose Knowledge?: Thinking from Women's Lives. Ithaca, New York: Cornell University Press. 
1993. Rethinking standpoint epistemology: What is "strong objectivity"? In Feminist epistemologies, ed. Linda Alcoff and Elizabeth Potter. New York and Oxford: Routledge.

Hartsock, Nancy. 1983. The feminist standpoint: Developing the ground for a specifically feminist historical materialism. In Discovering reality: Feminist perspectives on epistemology, metaphysics, methodology, and philosophy of science, ed. Sandra Harding and Merrill B. Hintikka. Dordrecht: Reidel Publishing Company.

Haslanger, Sally. 2008. Changing the ideology and culture of philosophy: Not by reason (alone). Hypatia 23 (2): 210-23.

Hochschild, Arlie Russell. 1985. The managed heart: Commercialization of human feeling. Berkeley: University of California Press.

Hochschild, Arlie Russell, and Anne Machung. 1989. The second shift: Working families and the revolution at home. New York: Penguin.

Intemann, Kristen. 2010. 25 years of feminist empiricism and standpoint theory: Where are we now? Hypatia 25 (4): 778-96.

Jaggar, Alison M. 1983. Feminist politics and human nature. Lanham, Md.: Rowman \& Littlefield.

Joseph, Tiffany D., and Laura E. Hirshfield. 2011. "Why don't you get somebody new to do it?" Race and cultural taxation in the academy. Ethnic and Racial Studies 34 (1): 121-41.

Kukla, Rebecca. 2006. Objectivity and perspective in empirical knowledge. Episteme 3 (1): 80-95.

Lukács, Georg. 1923/1971. History and class consciousness: Studies in Marxist dialectics. Trans. Rodney Livingstone. London: Merlin Press.

MacKinnon, Catherine A. 1991. Toward a feminist theory of the state. Cambridge, Mass.: Harvard University Press.

Manne, Kate. 2018. Down girl: The logic of misogyny. Oxford: Oxford University Press.

Marx, Karl, and Friedrich Engels. 1932/2001. From economic and philosophic manuscripts of 1844. In The Norton anthology of theory and criticism, ed. Vincent B. Leitch. New York: W. W. Norton \& Company.

Marx, Karl. 1867/1976. Capital: A critique of political economy. Trans. Ben Fowkes. London: Penguin.

Müller, Mirjam. 2018. Emotional labour: A case of gender-specific exploitation. Critical Review of International Social and Political Philosophy: 1-22.

Nair, Shelia. 2014. Women of color faculty and the "burden" of diversity. International Feminist Journal of Politics 16 (3): 497-500.

Onyejiaka, Tiffany. 2017. Hollywood's colorism problem can't be ignored any longer. Teen Vogue, August 22. https://www.teenvogue.com/story/hollywoods-colorism-problem-ca nt-be-ignored.

Pohlhaus, Gaile. 2011. Relational knowing and epistemic injustice: Toward a theory of willful hermeneutical ignorance. Hypatia 27 (4): 715-35.

Pratto, Felicia, James Sidanius, Lisa M. Stallworth, and Bertram F. Malle. 1994. Social dominance orientation: A personality variable predicting social and political attitudes. Journal of Personality and Social Psychology 67 (4): 741-63.

Railton, Peter. 1994. Truth, reason, and the regulation of belief. Philosophical Issues 5: 7193. 
Rolin, Kristina. 2009. Standpoint theory as a methodology for the study of power relations. Hypatia 24 (4): 218-26.

Rubin, Gayle. 1975. The traffic in women: Notes on the "political economy" of sex. In Toward an anthropology of women, ed. Rayna Reiter. New York: Monthly Review Press.

Ruth, Sheila. 1973. A serious look at consciousness-raising. Social Theory and Practice 2 (3): 289-300.

Ryan, Rebecca M. 1995. The sex right: A legal history of the marital rape exemption. Law Eु Social Inquiry 20 (4): 941-1001.

Sidanius, Jim, and Felicia Pratto. 1999. Social dominance: An intergroup theory of social hierarchy and oppression. Cambridge, UK: Cambridge University Press.

Smith, Dorothy. 1974. Women's perspective as a radical critique of sociology. Sociological Inquiry 44 (1): 7-13.

Social Sciences Feminist Network Research Interest Group. 2017. The burden of invisible work in academia: Social inequalities and time use in five university departments. Humboldt Journal of Social Relations 39: 228-45.

Spaapen, J., and L. van Drooge. 2011. Introducing "productive interactions" in social impact assessment. Research Evaluation 20 (3): 211-18.

Steele, Claude M. 2010. Whistling Vivaldi: How stereotypes affect us and what we can do. New York: W. W. Norton \& Company.

Sue, Derald Wing. 2010. Microaggressions in everyday life: Race, gender, and sexual orientation. Hoboken, N.J.: Wiley.

Toole, Briana. 2017. "Demarginalizing standpoint epistemology." PhD Diss. University of Texas.

Valian, Virginia. 1998. Schemas that explain behavior. In Why so slow?: The advancement of women. Cambridge, Mass: MIT Press.

Velleman, J. David. 2000. On the aim of belief. In The possibility of practical reason. Oxford: Oxford University Press.

Walker, Alice. 1983. In search of our mothers' gardens: Womanist prose. New York: Harcourt Brace Jovanovich.

Walzer, Susan. 1996. Thinking about the baby: Gender and divisions of infant care. Social Problems 43 (2): 219-34.

Wilson, Cherry. 2018. Colourism: Do light-skinned black women have it easier in showbiz? BBC News, June 4. https://www.bbc.com/news/newsbeat-44229236.

Wylie, Alison. 2003. Why standpoint matters. In Science and other cultures: Diversity in the philosophy of science and technology, ed. Robert Figueroa and Sandra G. Harding. New York and London: Routledge.

Young, Iris. 1980. Socialist feminism and the limits of dual systems theory. Socialist Review $10(2 / 3):$ 169-88. 